\title{
Antibiotic resistance and extended-spectrum $\beta$-lactamase in Escherichia coli isolates from imported 1-day-old chicks, ducklings, and turkey poults
}

\author{
Mona A. A. AbdelRahman ${ }^{1}$, Heba Roshdy ${ }^{1}$, Abdelhafez H. Samir ${ }^{2}$ and Engy A. Hamed ${ }^{1}$
}

\begin{abstract}
1. Department of Bacteriology, Reference Laboratory for Veterinary Quality Control on Poultry Production, Animal Health Research Institute, Agriculture Research Center, P.O. Box 264, Dokki, Giza 12618, Egypt; 2. Department of Biotechnology, Reference Laboratory for Veterinary Quality Control on Poultry Production, Animal Health Research Institute, Agriculture Research Center, P.O. Box 264, Dokki, Giza 12618, Egypt.

Corresponding author: Mona A. A. AbdelRahman, e-mail: drmonaali2000@yahoo.com

Co-authors: HR: roshdy2019@yahoo.com, AHS: abdelhafez_samir@yahoo.com, EAH: drengyahmed_2020@yahoo.com Received: 15-11-2019, Accepted: 16-04-2020, Published online: 10-06-2020
\end{abstract}

doi: www.doi.org/10.14202/vetworld.2020.1037-1044 How to cite this article: AbdelRahman MAA, Roshdy H, Samir AH, Hamed EA (2020) Antibiotic resistance and extended-spectrum $\beta$-lactamase in Escherichia coli isolates from imported 1-day-old chicks, ducklings, and turkey poults, Veterinary World, 13(6): 1037-1044.

\begin{abstract}
Aim: Antimicrobial resistance is a global health threat. This study investigated the prevalence of Escherichia coli in imported 1-day-old chicks, ducklings, and turkey poults.

Materials and Methods: The liver, heart, lungs, and yolk sacs of 148 imported batches of 1-day-old flocks (chicks, 45; ducklings, 63; and turkey poults, 40) were bacteriologically examined for the presence of E. coli.

Results: We isolated 38 E. coli strains from 13.5\%, 6.7\%, and 5.4\% of imported batches of 1-day-old chicks, ducklings, and turkey poults, respectively. They were serotyped as O91, O125, O145, O78, O44, O36, O169, O124, O15, O26, and untyped in the imported chicks; O91, O119, O145, O15, O169, and untyped in the imported ducklings; and O78, O28, O29, O168, O125, O158, and $\mathrm{O} 115$ in the imported turkey poults. The E. coli isolates were investigated for antibiotic resistance against 16 antibiotics using the disk diffusion method and were found resistant to cefotaxime (60.5\%), nalidixic acid $(44.7 \%)$, tetracycline $(44.7 \%)$, and trimethoprim-sulfamethoxazole $(42.1 \%)$. The distribution of extended-spectrum $\beta$-lactamase (ESBL) and $\operatorname{amp} C \beta$-lactamase genes was bla ${ }_{\mathrm{TEM}}(52.6 \%)$, bla $_{\mathrm{SHV}}(28.9 \%)$, bla $_{\text {СТХ-м }}(39.5 \%), b l a_{\text {OXА-1 }}(13.1 \%)$, and $\operatorname{amp} C(28.9 \%)$.
\end{abstract}

Conclusion: Imported 1-day-old poultry flocks may be a potential source for the dissemination of antibiotic-resistant $E$. coli and the ESBL genes in poultry production.

Keywords: Escherichia coli, extended-spectrum $\beta$-lactamase, imported, multidrug resistance, poultry.

\section{Introduction}

The global spread of antibiotic-resistant bacteria poses a potential threat to public health. The most important type of antibiotic resistance is that to $\beta$-lactamases, which has emerged as the result of the production of antibiotics containing $\beta$-lactamase-hydrolyzing enzymes because of the massive use of penicillins, cephalosporins, and carbapenems [1]. The global spread of extended-spectrum $\beta$-lactamase (ESBL) genes plays an essential role in the development of antibiotic resistance, which can be transmitted to humans through the consumption of animals for food, such as poultry, or by direct contact with contaminated poultry and their byproducts [2]. There are multiple routes of transmission of antibiotic-resistant bacteria, including plasmids, whole bacterial transmission, or mobile genetic element-mediated transmission [2,3]. The

Copyright: AbdelRahman, et al. Open Access. This article is distributed under the terms of the Creative Commons Attribution 4.0 International License (http://creativecommons.org/licenses/ by/4.0/), which permits unrestricted use, distribution, and reproduction in any medium, provided you give appropriate credit to the original author(s) and the source, provide a link to the Creative Commons license, and indicate if changes were made. The Creative Commons Public Domain Dedication waiver (http:// creativecommons.org/publicdomain/zero/1.0/) applies to the data made available in this article, unless otherwise stated. prolonged, uncontrolled use of $\beta$-lactam antimicrobials to treat many bacterial infections caused by members of the Enterobacteriaceae family, such as Escherichia coli, has resulted in the development of ESBL genes. Consequently, the number of $\beta$-lactamase-producing bacteria has increased [4]. An increase in the percentage of $\beta$-lactamase-producing $E$. coli has been observed among humans and in food samples, which are a potential serious risk to public health because of the considerable number of multidrug-resistant (MDR) genes [5].

$E$. coli is a Gram-negative bacterium that is a commensal in the gastrointestinal tracts of humans and animals, contributing to the development of antimicrobial resistance in commensal gut flora, which has an effect on the selection of antimicrobial agents as well as the spread of antimicrobial resistance [6]. E. coli is also important pathogen that causes diarrhea and death among humans and animals, and its presence gives an indication of the environmental status in poultry farms [7]. Moreover, it causes diseases in poultry, such as septicemia, swollen head syndrome, umbilical cord inflammation, egg yolk peritonitis, and chronic respiratory disease, resulting in reduced egg production and carcass condemnation, leading to drastic economic losses $[7,8]$. ESBLs hydrolyze the 
$\beta$-lactam ring in $\beta$-lactam antibiotics, giving rise to resistance to most $\beta$-lactam antibiotics, such as penicillins, cephalosporins, and the monobactam aztreonam. In addition, ESBL-producing Enterobacteriaceae have shown resistance to other antibiotic families, such as fluoroquinolones, trimethoprim-sulfamethoxazole (SXT), aminoglycosides, and tetracyclines, resulting in inadequate treatment [9-11]. TEM, SHV, and CTX-M are important families of ESBL enzymes that can destroy first-, second-, and third-generation cephalosporins, penicillin, and aztreonam. The $\beta$-lactamase inhibitors clavulanic acid and sulbactam can hinder the action of ESBL enzymes. ampC $\beta$-lactamases degrade first-, second-, and third-generation cephalosporins, penicillin, and aztreonam and are not suppressed by clavulanic acid or other $\beta$-lactamase inhibitors $[12,13]$. OXA is a plasmid-mediated $\beta$-lactamase that belongs to class D carbapenemases [13].

The study aimed to detect the prevalence of E. coli in imported chicks, ducklings, and turkey poults and to determine the prevalence ESBL and ampC genes.

\section{Materials and Methods}

\section{Ethical approval}

The study procedure was approved by the Reference Laboratory for Veterinary Quality Control on Poultry Production, Animal Health Research Institute, Egypt.

\section{Samples}

We tested 15 samples each from 148 batches (45 chick, 63duckling, and 40 turkey poults) of imported 1-day-old flocks that had been quarantined for the detection of epizootic disease before entry into Egypt.

Bacteriological examination was conducted when the chicks, ducklings, and turkey poults were 15 days old. The parenchymatous organs (i.e., liver, heart, lungs, and yolk sacs) were pooled as previously described [14] (four pools of 15 livers, 15 hearts, 15 lungs, and 15 yolk sacs, respectively, per batch). Each pool was used for $E$. coli isolation and subsequent antimicrobial susceptibility testing. The total number of examined samples is shown in Table-1.

\section{Isolation and identification of $E$. coli}

E. coli isolation and serotyping were performed as previously described $[15,16]$. On the day of arrival from the quarantine to the laboratory, the samples were enriched in Buffered Peptone Water at $37^{\circ} \mathrm{C}$ for $24 \mathrm{~h}$ and then samples were streaked on MacConkey agar (Oxoid Ltd., Basingstoke, UK) and incubated aerobically at $37^{\circ} \mathrm{C}$ for $24 \mathrm{~h}$. Lactose-fermenting colonies were then picked and re-streaked on eosin methylene blue agar (Oxoid Ltd.) and incubated for $24 \mathrm{~h}$ at $37^{\circ} \mathrm{C}$. Colonies with a green, metallic sheen were considered E. coli. These colonies were further biochemically tested for growth on triple sugar iron agar and lysine iron agar as well as for citrate utilization, urease production, and indole fermentation.
Table-1: Samples from examined imported flocks.

\begin{tabular}{lccc}
\hline Poultry spp. & $\begin{array}{c}\text { No. of } \\
\text { examined } \\
\text { batches }\end{array}$ & $\begin{array}{c}\text { No. of } \\
\text { subsamples }\end{array}$ & Total \\
\hline $\begin{array}{l}\text { One-day-old } \\
\text { chicks }\end{array}$ & 45 & 4 & 180 \\
$\begin{array}{l}\text { One-day-old } \\
\text { ducklings }\end{array}$ & 63 & 4 & 252 \\
$\begin{array}{l}\text { One-day-old } \\
\text { turkey poults } \\
\text { Number of }\end{array}$ & 40 & 4 & 160 \\
tested batches & 148 & & $\begin{array}{c}\text { Total no. of } \\
\text { samples 592 }\end{array}$ \\
\hline
\end{tabular}

\section{Determination of antimicrobial sensitivity}

The antimicrobial sensitivity was assessed according to the Clinical and Laboratory Standards Institute (CLSI) guidelines [17] using the KirbyBauer disk diffusion method on Mueller-Hinton agar plates (Oxoid) against 16 antibiotics (Oxoid), namely, penicillin $\mathrm{G}(10 \mathrm{U})$, amoxicillin + clavulanic acid (10$20 \mu \mathrm{g})$, cefotaxime (30 $\mu \mathrm{g})$, imipenem (10 mg), SXT $(1.25-23.75 \mu \mathrm{g})$, streptomycin $(10 \mu \mathrm{g})$, gentamycin $(10 \mu \mathrm{g})$, doxycycline $(30 \mu \mathrm{g})$, tetracycline $(30 \mu \mathrm{g})$, norfloxacin $(10 \mu \mathrm{g})$, levofloxacin $(5 \mu \mathrm{g})$, ciprofloxacin $(5 \mu \mathrm{g})$, nalidixic acid $(30 \mu \mathrm{g})$, chloramphenicol (30 $\mu \mathrm{g})$, erythromycin $(15 \mu \mathrm{g})$, and nitrofurantoin $(300 \mu \mathrm{g})$.

The susceptibility of $E$. coli isolates to individual antimicrobial agents was determined and interpreted the following aerobic incubation at $37^{\circ} \mathrm{C}$ for $18-24 \mathrm{~h}$, according to CLSI guidelines. Test results were considered valid if the diameters of the inhibition zones of the control E. coli strain (ATCC 25922) were within the performance ranges.

\section{Detection of ESBL and ampC genes for $E$. coli}

DNA was extracted from the samples using aQIAamp DNA Mini Kit (Qiagen, Hilden, Germany) with modifications to the manufacturer's recommendations. Briefly, $200 \mu \mathrm{l}$ of the sample suspension was incubated with $10 \mu \mathrm{l}$ of proteinase $\mathrm{K}$ and $200 \mu \mathrm{l}$ of lysis buffer at $56 \mathrm{~L}$ for $10 \mathrm{~min}$ thereafter, $200 \mu \mathrm{l}$ of $100 \%$ ethanol was added to the lysate. The sample was then washed and centrifuged according to the manufacturer's instructions. The extracted DNA was eluted with $100 \mu l$ of elution buffer.

We performed polymerase chain reaction (PCR) on the extracted DNA samples. The primers (Metabion, Planegg-Martinsried, Germany) are detailed in Table-2 [18-20]. PCR was performed using an Applied Biosystems 2720 Thermal Cycler (Foster City, CA, USA) in a final reaction volume of $25 \mu \mathrm{l}$ containing $12.5 \mu \mathrm{l}$ of Emerald Amp MAX PCR Master Mix (Takara, Shiga, Japan), $1 \mu$ of each primer $(20 \mathrm{pM}), 4.5 \mu \mathrm{l}$ of $\mathrm{H}_{2} \mathrm{O}$, and $6 \mu 1$ of DNA template. The PCR products $(20 \mu \mathrm{g} /$ lane $)$ were separated by electrophoresis on 1.5\% agarose gel (Applichem $\mathrm{GmbH}$, Darmstadt, Germany) in $1 \times$ Tris-borate-EDTA buffer at room temperature using a gradient of $5 \mathrm{~V} /$ cm. A. 100-1000-bp DNA ladder (GenedireX Inc., 


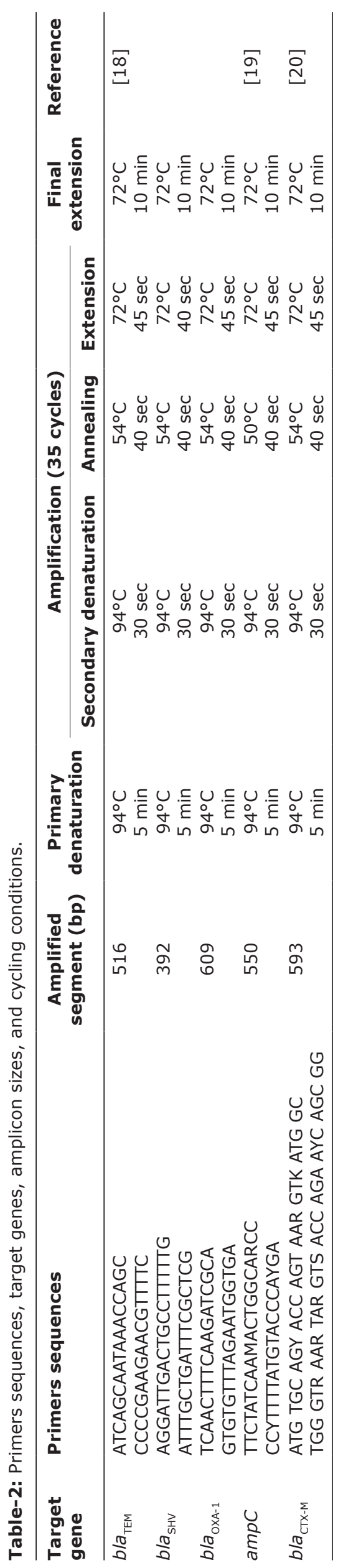

Flint Place Poway, CA, USA) was used to determine the fragment sizes. The gel was photographed by an Alpha Innotech gel documentation system (Biometra $\mathrm{GmbH}$, Göttingen, Germany), and the data were analyzed using the associated system software.

\section{Results}

\section{E. coli isolation}

E. coli infections in the internal organs of apparently healthy 1-day-old imported batches of flocks presented as heart and lung congestion, pneumonia, pericarditis, perihepatitis, and omphalitis on postmortem examination. We detected E. coli in $25.6 \%$ $(38 / 148)$ of the total examined samples. The recovery rates after $E$. coli isolation from the imported chicks, ducklings, and turkey poult samples were $13.5 \%$, $6.7 \%$, and $5.4 \%$, respectively (Table-3).

\section{Serotyping of $E$. coli isolates}

We identified 17 serotypes in the $E$. coli isolates, of which the most common were O91, O125, O145, O78, O169, O15, and untyped isolates. The untyped isolates were unable to be typed using the antisera available in Egypt. The serotype distribution was O91, O125, O145, O78, O44, O36, O169, O124, O15, O26, and untyped in the imported chicks; O91, O119, O145, O15, O169, and untyped in the imported ducklings; and $\mathrm{O} 78, \mathrm{O} 28, \mathrm{O} 29, \mathrm{O} 168, \mathrm{O} 125, \mathrm{O} 158$, and O115 in the imported turkey poults.

\section{Antimicrobial sensitivity of isolated $E$. coli strains}

The highest rate of resistance was found to cefotaxime $(60.5 \%)$, tetracycline $(44.7 \%)$, nalidixic acid (44.7\%), and SXT (42.1\%). A moderate resistance rate was shown to streptomycin $(36.8 \%)$, doxycycline $(26.3 \%)$, ciprofloxacin $(26.3 \%)$, and norfloxacin (21\%). The E coli isolates were most susceptible to gentamycin (18.4\%), levofloxacin (15.8\%), nitrofurantoin (12.5\%), chloramphenicol (12.5\%), amoxicillin-clavulanic acid (5.2\%), and imipenem (2.6\%) (Tables-4 and 5). Of the E. coli isolates, 22/38 (57.8\%) were MDR because they showed resistance to three or more classes of antimicrobial agents, excluding erythromycin and penicillin (Table-5).

Molecular detection of ESBL and ampC genes in E. coli strains

We identified one or more ESBL and/or ampC genes in $32 / 38 \mathrm{E}$. coli isolates $(84.2 \%)$. bla TEM $_{\text {was }}$

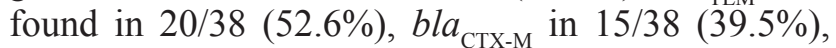
bla $_{\mathrm{OXA}-1}$ in $5 / 38(13.1 \%)$, and $b l a_{\mathrm{SHV}}$, and $a m p C$ in $11 / 38(28.9 \%)$ isolates each.

\section{Discussion}

Although many studies have been conducted on the prevalence of $E$. coli in 1-day-old flocks, limited data were found on the prevalence of $E$. coli in imported 1-day-old flocks. E. coli is one of the most commonly spread bacterial pathogens in poultry worldwide and is responsible for colibacillosis, which usually presents as either a localized or systemic 
Table-3: Incidence of $E$. coli was isolated from imported flocks as follow.

\begin{tabular}{|c|c|c|c|c|c|}
\hline Flock type & $\begin{array}{c}\text { No. of } \\
\text { examined } \\
\text { flock batches }\end{array}$ & $\begin{array}{l}\text { No. of isolated } \\
\text { E. coli from each } \\
\text { batch }\end{array}$ & $\begin{array}{l}\text { Incidence of } \\
E . \text { coli/each } \\
\text { flock batches }\end{array}$ & $\begin{array}{l}\text { Incidence of } \\
E . \text { coli/total } \\
\text { flock batches }\end{array}$ & Serogroups \\
\hline Imported chicks & 45 & 20 & $44.4 \%(20 / 45)$ & $13.5 \%(20 / 148)$ & $\begin{array}{c}\text { 091, 0125, 0145, } \\
\text { O78, 044, O36, O169, } \\
\text { O124, 015, O26, (5) } \\
\text { untyped isolates }\end{array}$ \\
\hline Imported ducklings & 63 & 10 & $15.8 \%(10 / 63)$ & $6.7 \%(10 / 148)$ & $\begin{array}{c}\text { 091, 0119, O145, } \\
\text { O15, 0169, (1) } \\
\text { untyped isolate. }\end{array}$ \\
\hline Imported turkey poults & 40 & 8 & $20 \%(8 / 40)$ & $5.4 \%(8 / 148)$ & $\begin{array}{c}\text { O78, O28, O29, O168, } \\
0125,0158,0115\end{array}$ \\
\hline Total & 148 & 38 & & $25.6 \%(38 / 148)$ & \\
\hline
\end{tabular}

E. coli=Escherichia coli

Table-4: Antibiotic susceptibility of 38 E. coli isolates from imported flocks using disk diffusion.

\begin{tabular}{llccc}
\hline Antimicrobial class & Antimicrobial agent & $\begin{array}{c}\text { Sensitive } \\
\text { rate (\%) }\end{array}$ & $\begin{array}{c}\text { Intermediate } \\
\text { sensitive (\%) }\end{array}$ & $\begin{array}{c}\text { Resistant } \\
\text { rate (\%) }\end{array}$ \\
\hline B-lactams & Penicillin & 0 & 0 & 100 \\
$\beta$-lactam/ $\beta$-lactamase inhibitor & Amoxicillin-clavulanic acid & 79 & 15.8 & 5.2 \\
$\beta$-lactam (cephalosporin) & Cefotaxime & 39.5 & 0 & 60.5 \\
$\beta$-lactam (carbapenem) & Imipenem & 97.4 & 0 & 2.6 \\
Sulfonamides & Trimethoprim/sulfamethoxazole & 44.8 & 13.1 & 42.1 \\
Aminoglycosides & Streptomycin & 39.5 & 23.7 & 36.8 \\
Tetracycline & Gentamycin & 71 & 10.6 & 18.4 \\
& Doxycycline & 42.1 & 31.6 & 26.3 \\
Fluoroquinolones & Tetracycline & 39.6 & 15.7 & 44.7 \\
& Norfloxacin & 71 & 8 & 21 \\
Quinolones & Levofloxacin & 84.2 & 0 & 15.8 \\
Phenicols & Ciprofloxacin & 68.5 & 5.2 & 26.3 \\
Macrolide & Nalidixic acid & 52.6 & 2.7 & 44.7 \\
Nitrofurans & C30 & 86.9 & 0 & 13.1 \\
\hline
\end{tabular}

infection, leading to body weight loss and the contamination of a considerable number of carcasses during slaughter [21].

In our study, the prevalence of E. coli in 1-dayold imported flocks was $25.6 \%$, which was slightly higher than the prevalence that was recorded in Dutch farms in 2-day-old grandparent stock chickens of broiler Breed A (23\%) [22], but lower than prevalence rates reported in imported baby chicks in Egypt (44\%) [23], 1-day-old chick Breed B in Dutch farms (44\%) [22], and 1-day-old domestic and imported chicks in Egypt (60\%) [24].

The prevalence of E. coli in imported duckling flocks in our study was $15.8 \%$, which was higher than previously recorded in ducklings in Egypt (11.3\%) [25]. In our study, the incidence of E. coli was $44 \%$ in imported chick flocks which are considerably higher than the incidence mentioned in 1-day-old chicks in Egypt (24\% and 23.6\% in Roshdy et al. [26] and Abdelrahman et al. [27], respectively). In the existing literature, the prevalence of E. coli in turkey poults flocks was $20 \%$, which was lower than that reported in 1-day-old poults in Egypt (30\% in 1-dayold) [28] but higher than the rate of another study $(15 \%)$ conducted in Egypt [29]. In our study, 13.1\% of $E$. coli isolates serotyped as O91, while in another
Egyptian study, O91 was found in $5.8 \%$ and $4 \%$ of E. coli isolates from chicken and 1-day-old ducklings, respectively [26]. On the other hand, E. coli serotype $\mathrm{O} 15$ was identified in $10.5 \%$, in our study, while $\mathrm{O} 15$ was detected in $4.1 \%$ of 1-day-old domestic and imported chicks in Egypt [24].

Multidrug resistance may emerge from the transmission of $E$. coli during hatching, breeding, and movement from one country to another, and the importation of poultry may also be regarded as another route of transmission of ESBL and $a m p C$ genes [22]. The development of the resistance to several antibiotics, such as gentamycin, SXT, ciprofloxacin, and cefotaxime, occurs due to their uncontrolled usage in treatment, or as growth promoters or prophylactics [30,31].

The global issue of antimicrobial resistance is steadily worsening. In this study, we examined the antimicrobial resistance of $38 \mathrm{E}$. coli isolates from imported poultry and found variable resistance rates. The high rates of resistance to tetracycline, SXT, and streptomycin as well as the low rates of resistance to gentamycin, norfloxacin, and ciprofloxacin, in our study, were in agreement with the results of a previous report from 1-day-old chicks in Egypt [24]. The rates of the antimicrobial resistance of isolated E. coli for amoxicillin-clavulanic acid, gentamycin, tetracycline, 
Table-5: Results of $b / a_{\mathrm{TEM},}$ bla $\mathrm{SHV}_{\text {, }}$ bla $\mathrm{CTX}-\mathrm{M}$, bla $\mathrm{OXX}_{\mathrm{A}-1}$ and $a m p C$ genes and antibiotic resistance pattern among Escherichia coli isolates.

\begin{tabular}{|c|c|c|c|c|}
\hline Strain & Serotype & Source & Phenotypic antibiotic resistance & Resistance genes identified \\
\hline \multicolumn{5}{|l|}{ Chicks } \\
\hline 1 & 091 & Chicks & $\mathrm{P}, \mathrm{E}, \mathrm{CTX}, \mathrm{SXT}, \mathrm{S}^{10}, \mathrm{~T}^{30}, \mathrm{NA}^{30}$ & $b / a_{\text {TEM }}$ \\
\hline 2 & 091 & Chicks & $\mathrm{P}, \mathrm{E}, \mathrm{SXT}$ & \\
\hline 3 & 091 & Chicks & P, E, CTX, SXT & bla $_{\text {СТX-M }}$ \\
\hline 4 & 091 & Chicks & $\mathrm{P}, \mathrm{E}, \mathrm{CF} 5$ & \\
\hline 5 & 0125 & Chicks & $\mathrm{P}, \mathrm{E}, \mathrm{S} X \mathrm{~T}, \mathrm{~S}^{10}, \mathrm{DO}^{30}, \mathrm{~T}^{30}, \mathrm{NA}^{30}, \mathrm{~F}^{300}$ & bla $_{\mathrm{SHV}}$ \\
\hline 6 & 0122 & Chicks & $\mathrm{P}, \mathrm{E}, \mathrm{CTX}, \mathrm{SXT}, \mathrm{G}^{10}, \mathrm{~T}^{30}, \mathrm{Lev}, \mathrm{NA}^{30}$ & $b / a_{\mathrm{TEM}}{ }^{\prime} b l a_{\mathrm{SH}{ }^{\prime}}$ ampc \\
\hline 7 & 0145 & Chicks & $\mathrm{P}, \mathrm{E}, \mathrm{CTX}, \mathrm{S}^{10}, \mathrm{DO}^{30}, \mathrm{C}^{30}$ & bla ${ }_{\mathrm{SH} \mathbf{y}^{\prime}}$ ampC, bla \\
\hline 8 & 0145 & Chicks & $\mathrm{P}, \mathrm{E}, \mathrm{CTX}$ & $b^{\prime} / a_{\mathrm{SHV}}$ bla $a_{\mathrm{CTX}-\mathrm{M}}$ \\
\hline 9 & 078 & Chicks & $\mathrm{P}, \mathrm{E}, \mathrm{CTX}, \mathrm{SXT}, \mathrm{DO}^{30}, \mathrm{~T}^{30}, \mathrm{NA}^{30}$ & bla $a_{\mathrm{SHV}}$ \\
\hline 10 & 078 & Chicks & $\mathrm{P}, \mathrm{E}, \mathrm{CTX}, \mathrm{SXT}, \mathrm{DO}^{30}, \mathrm{~T}^{30}, \mathrm{NA}^{30}$ & bla \\
\hline 11 & 044 & Chicks & $\mathrm{P}, \mathrm{E}, \mathrm{CTX}, \mathrm{NA}^{30}$ & bla \\
\hline 12 & 036 & Chicks & $\mathrm{P}, \mathrm{E}$ & \\
\hline 13 & UN & Chicks & $\mathrm{P}, \mathrm{E}, \mathrm{NX}^{10}, \mathrm{CF} 5, \mathrm{IMP}$ & $a m p C$ \\
\hline 14 & UN & Chicks & $\mathrm{P}, \mathrm{E}, \mathrm{CTX}, \mathrm{SXT}, \mathrm{S}^{10}, \mathrm{G}^{10}, \mathrm{~T}^{30}, \mathrm{NX}^{10}, \mathrm{CF} 5, \mathrm{NA}^{30}, \mathrm{C}^{30}$ & bla $_{\mathrm{TEM}}$, bla $\mathrm{OXA}-1^{\prime}$ bla \\
\hline 15 & UN & Chicks & $\mathrm{P}, \mathrm{E}, \mathrm{CTX}, \mathrm{SXT}, \mathrm{S}^{10}, \mathrm{NX}^{10}, \mathrm{CF} 5, \mathrm{NA}^{30}, \mathrm{~F}^{300}$ & 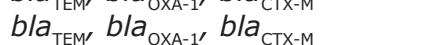 \\
\hline 16 & UN & Chicks & $P, E$ & bla $a_{\text {TEM }}$ \\
\hline 17 & 0124 & Chicks & $P, E, C T X, G^{10}, N A^{30}$ & bla $\mathrm{T}_{\mathrm{TEM}}$ \\
\hline 18 & UN & Chicks & $\mathrm{P}, \mathrm{E}, \mathrm{T}^{30}, \mathrm{C}^{30}$ & bla \\
\hline 19 & 026 & Chicks & $\mathrm{P}, \mathrm{E}, \mathrm{S}^{10}$ & bla $a_{\mathrm{TEM}}, b / a_{\mathrm{CTX}-\mathrm{M}}$ \\
\hline 20 & 078 & Chicks & $\mathrm{P}, \mathrm{E}, \mathrm{S}^{10}$ & \\
\hline \multicolumn{5}{|c|}{ Ducklings } \\
\hline 1 & 091 & Ducklings & $\mathrm{P}, \mathrm{NA}, \mathrm{LEV}, \mathrm{E}, \mathrm{T}^{30}, \mathrm{~S}^{10}, \mathrm{SXT}, \mathrm{F}^{300}$ & $a m p C$ \\
\hline 2 & 0119 & Ducklings & $\mathrm{P}, \mathrm{E}, \mathrm{CTX}, \mathrm{S}^{10}, \mathrm{~T}^{30}, \mathrm{NA}^{30}, \mathrm{AMC}$ & bla $_{\mathrm{TEM} \mathrm{M}^{\prime}}$ ampc, bla \\
\hline 3 & 0145 & Ducklings & $\mathrm{P}, \mathrm{E}, \mathrm{S}^{10}$ & $a m p C$ \\
\hline 4 & 036 & Ducklings & $\mathrm{P}, \mathrm{E}, \mathrm{NX}^{10}, \mathrm{NA}^{30}, \mathrm{CF} 5, \mathrm{CTX}$ & bla $_{\mathrm{SHV}}$ \\
\hline 5 & 0169 & Ducklings & $\mathrm{P}, \mathrm{E}, \mathrm{CTX}, \mathrm{SXT}, \mathrm{T}^{30}$ & $b l a_{\mathrm{TEM}}$ \\
\hline 6 & 015 & Ducklings & $\mathrm{P}, \mathrm{E}, \mathrm{CTX}, \mathrm{SXT}, \mathrm{T}^{30}$ & bla $a_{\mathrm{TEM}}$, bla $_{\mathrm{SHV}}$ \\
\hline 7 & UN & Ducklings & $\mathrm{P}^{\prime} \mathrm{E}, \mathrm{CTX}$ & $b^{\prime} / a_{\mathrm{TEM}}, b l a_{\mathrm{OXA}-1}, a m p c, b l a_{\mathrm{CTX}-\mathrm{M}}$ \\
\hline 8 & 015 & Ducklings & $\mathrm{P}, \mathrm{E}, \mathrm{CTX}, \mathrm{SXT}, \mathrm{S}^{10}, \mathrm{G}^{10}, \mathrm{~T}^{30}, \mathrm{NX} X^{10}, \mathrm{CF} 5, \mathrm{NA}^{30}, \mathrm{C}^{30}, \mathrm{~F}^{300}$ & bla $a_{\text {TEM' }}$ bla $a_{\text {CTX-M }}$ \\
\hline 9 & 015 & Ducklings & $\mathrm{P}, \mathrm{E}, \mathrm{C}^{30}$ & bla $a_{\mathrm{TEM}}$ bla $\mathrm{OXA}_{\mathrm{OA}-1}$ \\
\hline 10 & 015 & Ducklings & $\mathrm{P}, \mathrm{E}, \mathrm{S}^{10}, \mathrm{DO}^{30}, \mathrm{~T}^{30}, \mathrm{NX}^{10}, \mathrm{CF} 5, \mathrm{~F}^{300}$ & bla $a_{\mathrm{TEM}}, b l a_{\mathrm{SH} \mathrm{N}^{\prime}}$ bla $\mathrm{OXXA-1}, b l a_{\mathrm{CTX}-\mathrm{M}}$ \\
\hline \multicolumn{5}{|c|}{ 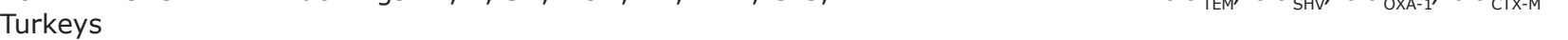 } \\
\hline 1 & 078 & Turkey & $\mathrm{P}, \mathrm{E}$ & \\
\hline 2 & $\mathrm{O} 28$ & Turkey & $\mathrm{P}, \mathrm{E}, \mathrm{CTX}, \mathrm{SXT}, \mathrm{DO}^{30}, \mathrm{Lev}, \mathrm{NA}^{30}, \mathrm{AMC}$ & $b / a_{\mathrm{TEM}}, a m p C$ \\
\hline 3 & $\mathrm{O} 28$ & Turkey & $\mathrm{P}, \mathrm{E}, \mathrm{CTX}, \mathrm{S}^{10}, \mathrm{DO}^{30}, \mathrm{~T}^{30}, \mathrm{Lev}, \mathrm{CF} 5, \mathrm{NA}^{30}$ & $b / a_{\mathrm{TEM}} b / a_{\mathrm{SH} \mathrm{V}^{\prime}}$ ampc, bla $a_{\mathrm{CTX}-\mathrm{M}}$ \\
\hline 4 & 029 & Turkey & $\mathrm{P}, \mathrm{E}, \mathrm{CTX}, \mathrm{DO}^{30}$ & bla $a_{\mathrm{TF},}$ ampc, bla \\
\hline 5 & 0168 & Turkey & $\mathrm{P}, \mathrm{E}, \mathrm{S}^{10}, \mathrm{G}^{10}, \mathrm{DO}^{30}, \mathrm{~T}^{30}$ & \\
\hline 6 & 0125 & Turkey & $\mathrm{P}, \mathrm{E}, \mathrm{CTX}, \mathrm{SXT}, \mathrm{G}^{10}, \mathrm{DO}^{30}, \mathrm{~T}^{30}, \mathrm{NX}^{10}, \mathrm{Lev}, \mathrm{CF} 5, \mathrm{NA}^{30}$ & $b^{\prime} a_{\mathrm{TEM}}, b / a_{\mathrm{SH}}, a m p C$ \\
\hline 7 & 0158 & Turkey & $\mathrm{P}, \mathrm{E}, \mathrm{CTX}, \mathrm{SXT}, \mathrm{S}^{10}, \mathrm{G}^{10}, \mathrm{~T}^{30}, \mathrm{NX}^{10}, \mathrm{Lev}, \mathrm{CF} 5, \mathrm{NA}^{30}, \mathrm{~F}^{300}$ & bla $a_{\mathrm{SHV}}, b l a_{\mathrm{CTX}-\mathrm{M}}$ \\
\hline 8 & 0115 & Turkey & $\mathrm{P}, \mathrm{E}, \mathrm{CTX}$ & bla \\
\hline
\end{tabular}

doxycycline, norfloxacin, and ciprofloxacin, in our study, were lower than those of $E$. coli isolates from turkey poults in Egypt [29] and higher than what was reported in a previous Egyptian study [24].

In Sweden, many cases of E. coli carrying ESBL or $\operatorname{ampC}$ resistance genes were recorded from the intestinal contents of broilers, and this was interpreted mainly as a consequence of the introduction of imported breeding stock in addition to antimicrobial use [32]. In addition, the global spread of MDR strains has caused a serious problem due to massive uncontrolled and random use of antimicrobials. In our study, $57.8 \%$ of $E$. coli isolates were MDR due to the exhibited resistance to at least one antimicrobial agent from three or more different antimicrobial classes [33]. In Egypt, two studies on E. coli isolates from turkey poults and day-old hatchlings showed that $100 \%$ [29] and $63.3 \%$ [34] were MDR, respectively. Collectively, these results are indicators of the frequent occurrence of MDR in the poultry industry.

Shortly after the release of the first extended-spectrum $\beta$-lactam antibiotics, bacterial resistance to such antibiotics began to emerge, and it has been reported as frequently increasing. The resultant therapeutic failures have turned into a worldwide problem [35]. In Europe, $b l a_{\mathrm{CTX}-\mathrm{M}}, b l a_{\mathrm{TEM}}$, and $b l a_{\mathrm{SHV}}$ have been recorded as the most predominant ESBL genes in compared with $\operatorname{ampC}$ [36]. Reports discussing the prevalence of ESBL-producing E. coli isolates from imported 1-dayold flocks in Egypt are scarce. Here, the $b l a_{\mathrm{TEM}}, b l \mathrm{a}_{\mathrm{SHV}}$, and $b l a_{\text {OXA-1 }}$ genes were detected in $52.6 \%, 28.9 \%$, and $13.1 \%$, respectively. Other studies have reported the aforementioned genes in $93.3 \%, 39.5 \%$, and $60.0 \%$, respectively, in $E$. coli isolates from 1-day-old hatchlings in Egypt [34]. In our study, bla $_{\mathrm{TEM}}$ and bla OXA-1 $_{1}$ genes were detected in $52.6 \%$ and $13.1 \%$ of all E. coli isolates, respectively. Another study showed a very 
similar rate of the detection of $b l a_{\mathrm{TEM}}$ and $b l a_{\mathrm{OXA}-1}$ genes (52.3\% and $14.3 \%$, respectively) in E. coli isolates from poultry and beef products in Egypt [37].

The antimicrobial resistance is a serious global health problem among humans and in the field of veterinary medicine, and the existence of $b l a_{\text {CTX-M }}$ may cause the transfer of antibiotic resistance from poultry to humans through food supply chains or through mobile genetic elements in the surrounding environment [38]. bla $a_{\text {СтХ-М }}$ was detected in $39.5 \%$ of E. coli isolates in this study. Furthermore, the $\beta$-lactamase-encoding genes $b l a_{\text {СТХ-M } 1}$ and $b l a_{\text {СTXM-2 }}$ were detected in E. coli isolates from parent stock chickens of broiler Breed A in Dutch farms and in production farms and environmental samples of hatchery units at the broiler hatchery [22]. ESBL - as well as ampC - producing bacteria are commonly found in the gastrointestinal tract of animals [39] and have been isolated from turkey $[40,41]$ and poultry [42]. The gastrointestinal tract of animals is seen as an important reservoir for bacteria that produce $\beta$-lactamases and as a potential source for human pathogens to take up these resistance genes $[39,41,43]$. ESBL and $a m p C$ genes that are located on plasmids are able to spread very rapidly [44]. The prevalence of $\operatorname{ampC}$ in both 1-day-old parent stock and 1-day-old broilers that were imported into the UK Dutch farms was $5.8 \%$ and $1.9 \%$, respectively, which is markedly less that of our current study $(28.9 \%)$ [22].

\section{Conclusion}

The results presented in this study reveal the high prevalence of E. coli among imported 1-day-old poultry batches. Increasing resistance to several antibiotics was also detected, such as the resistance to cefotaxime and tetracycline, which may transfer such antibiotic resistance to humans. The presence of $\beta$-lactamase and $\operatorname{ampC}$ genes in the food chains of humans may also contribute to the problem of antibiotic resistance, which will directly result in public health problems.

\section{Recommendations}

Surveys on the incidence and epidemiology of ESBL-producing E. coli in imported 1-day-old broilers shall be implemented and monitored. Furthermore, the controlled use of antibiotics is required to avoid the occurrence of antibiotic resistance to other antimicrobial drugs.

\section{Authors' Contributions}

MAAA, HR, and EAH designed the study, collected the samples, and applied bacteriological examinations. MA wrote the manuscript. AHS applied PCR testing. All authors have read and approved the final manuscript.

\section{Acknowledgment}

The authors are thankful to the Reference Laboratory for Veterinary Quality Control on Poultry Production Dokki, Egypt, for providing the resources for conduction of this study. The authors did not receive any funds for this study.

\section{Competing Interests}

The authors declare that they have no competing interests.

\section{Publisher's Note}

Veterinary World remains neutral with regard to jurisdictional claims in published map and institutional affiliation.

\section{References}

1. Abbas, G., Khan, I., Mohsin, M., Sajjad-Ur-Rahman, Y.T. and Ali, S. (2019) High rates of CTX-M group-1 extended-spectrum $\beta$-lactamases producing Escherichia coli from pets and their owners in Faisalabad, Pakistan. Infect. Drug Resist., 6(12): 571-578

2. Lazarus, B., Paterson, D.L., Mollinger, J.L. and Rogers, B.A. (2014) Do human extra-intestinal Escherichia coli infections resistant to expanded-spectrum cephalosporins originate from food-producing animals? A systematic review. Clin. Infect. Dis., 60(3): 439-452.

3. Falgenhauer, L., Imirzalioglu, C., Oppong, K., Akenten, C.W., Hogan, B., Krumkamp, R., Poppert, S., Levermann, V., Schwengers, O., Sarpong, N., OwusuDabo, E., May, J. and Eibach, D. (2019) Detection and characterization of ESBL-producing Escherichia coli from humans and poultry in Ghana. Front. Microbiol., 15(9): 3358 .

4. Allen, H.K., Donato, J., Wang, H.H., Cloud-Hansen, K.A., Davies, J. and Handelsman, J. (2010) Call of the wild: Antibiotic resistance genes in natural environments. Nat. Rev. Microbiol., 8(4): 251-259.

5. Chong, Y., Ito, Y. and Kamimura, T. (2011) Genetic evolution and clinical impact in extended spectrum beta-lactamase-producing Escherichia coli and Klebsiella pneumoniae. Infect. Genet. Evol., 11(7): 1499-1504.

6. Da Costa, P.M., Loureiro, L. and Matos, A.J.F. (2013) Transfer of multidrug-resistant bacteria between intermingled ecological niches: The interface between humans, animals and the environment. Int. J. Environ. Res. Public Health, 10(1): 278-294.

7. Bo, W., Duan, H., Qi, Q., Cai, Y., Zhong, Z. and Chai, T. (2018) Identifying virulence factor genes in E. coli in animal houses and their transmission to outside environments. J. Aerosol Sci., 117(3): 189-199.

8. Xie, Y., Kim, K.J. and Kim, K.S. (2004) Current concepts on Escherichia coli K1 translocation of the blood-brain barrier. FEMS Immunol. Med. Microbiol., 42(3): 271-279.

9. Ben-Ami, R., Rodríguez-Baño, J., Arslan, H., Pitout, J.D., Quentin, C., Calbo, E.S., Azap, O.K., Arpin, C., Pascual, A., Livermore, D.M., Garau, J. and Carmeli, Y. (2009) A multinational survey of risk factors for infection with extended-spectrum beta-lactamase-producing Enterobacteriaceae in nonhospitalized patients. Clin. Infect. Dis., 49(5): 682-690.

10. Sfeir, M.M., Askin, G. and Christos, P. (2018) Beta-lactam/ beta-lactamase inhibitors versus carbapenem for bloodstream infections due to extended-spectrum beta-lactamase-producing Enterobacteriaceae: Systematic review and meta-analysis. Int. J. Antimicrob. Agents, 52(5): 554-570.

11. Pitout, J.D. (2013) Enterobacteriaceae that produce extended-spectrum $\beta$-lactamases and AmpC $\beta$-lactamases in the community: The tip of the iceberg? Curr. Pharm. Des., 19(2): 257-263.

12. Philippon, A., Arlet, G. and Jacoby, G.A. (2002) Plasmiddetermined AmpC-type beta-lactamases. Antimicrob. 
Agents Chemother., 46(1): 1-11.

13. Moxon, C.A. and Paulus, S. (2016) Beta-lactamases in Enterobacteriaceae infections in children. J. Infect., 72(Suppl): S41-S49.

14. Middleton, J.R., Fales, W.H., Luby, C.D., Landsay, O.J., Kinyon, J.M.S., Wu, C.C., Maddox, C.W. and Hartmann, F. (2005) Surveillance of Staphylococcus aureus in veterinary teaching hospitals. J. Clin. Microbiol., 43(6): 2916-2919.

15. Lee, M.D. and Nolan, K.L. (2008) A laboratory manual for the isolation and identification of avian pathogen. In: Zavala, L.D., Swayne, D.E., John, R.C., Mark, W.G., Wood, J., Pearson, J.E. and Reed, W.M, editors. Editorial Board for the American Association of Avian Pathologists. $5^{\text {th }}$ ed., Ch. 3. American Association, Colibacillosis. p10-16.

16. Lee, G.Y., Jang, H.I., Hwang, I.G. and Rhee, M.S. (2009) Prevalence and classification of pathogenic Escherichia coli isolated from fresh beef, poultry, and pork in Korea. Int J. of Food Microbiol., 134(3): 196-200.

17. CLSI. (2015) Performance Standards for Antimicrobial Susceptibility Testing; $21^{\text {st }}$ Informational Supplement, M100S21. Standard by Clinical and Laboratory Standards Institute, Wayne, PA.

18. Colom, K., Pèrez, J., Alonso, R., Fernández-Aranguiz, A., Lariňo, E. and Cisterna, R. (2003) Simple and reliable multiplex PCR assay for detection of bla $\left._{\mathrm{TEM}}, \mathrm{bla}_{\mathrm{SHV}}\right)$ and bla $_{\text {OXA-1 }}$ genes in Enterobacteriaceae. FEMS Microbiol. Lett., 223(2): 147-151.

19. Srinivasan, V., Nam, .H.M., Nguyen, L.T., Tamilselvam, B., Murinda, S.E. and Oliver, S.P. (2005) Prevalence of antimicrobial resistance genes in Listeria monocytogenes isolated from dairy farms. Foodborne Pathog. Dis., 2(3): 201-211.

20. Archambault, M., Petrov, P., Hendriksen, R.S., Asseva, G., Bangtrakulnonth, A., Hasman, H. and Aarestrup, F.M. (2006) Molecular characterization and occurrence of extended-spectrum beta-lactamase resistance genes among Salmonella enterica serovar Corvallis from Thailand, Bulgaria, and Denmark. Microb. Drug Resist., 12(3): 192-198.

21. Nolan, L.K., Barnes, H.J., Vaillancourt, J.P., Abdul-Aziz, T. and Logue, C.M. (2013) Colibacillosis. In: Swayne D, editor. Diseases of Poultry. $13^{\text {th }}$ ed. Iowa State University Press, Ames. p751-806.

22. Dierikx, C.M., van der Goot, J.A., Smith, H.E., Kant A. and Mevius, D.J. (2013) Presence of ESBL/AmpC-producing Escherichia coli in the broiler production pyramid: A descriptive study. PLoS One, 8(11): e79005.

23. Abd El Tawab, A.A., Nasef, S.A. and Reda, M.R. (2015) Prevalence of E. coli in diseased chickens with its antibiogram pattern. Benha Vet. Med. J., 28(2): 224-230.

24. Saad, A.Z., Nasef, S.A., Elhariri, M., Elhelw, R. and Ezzeldeen, N. (2017) Resistance patterns associated with bacterial pathogens causing omphalitis in baby chicks. Biosci. Res., 14(4): 845-851.

25. Badr, H., AbdelRahman, M.A.A., Farghaly, E.M., Gaber, A., Roshdy, H. and Nasef, S.A. (2015) Characterization of some aerobic bacterial microorganisms isolated from newly hatched imported ducklings. Egypt. Poult. Sci., 35(4): 1123-1136.

26. Roshdy, H., Nasef, S.A. and Refai, M.( 2012) Incidence of E. coli in Chickens and Ducks in Different Governorates in Egypt. $1^{\text {st }}$ Conference of Scientific Association of Animal Health Research Institute. p420-426.

27. Abdelrahman, M.A.A., Hamed, E.A., Roshdy, H., Sorour, H.K. and AlAtfeehy, N.M. (2014) Bacteriological studies on native and imported apparently healthy one-day old chicks. Suez Canal Vet. Med. J., 19(2): 263-276.

28. Sorour, H.K., AlAtfeehy, N.M, Badr, H., Nasef, S.A. and Hamed, E.A. (2016) Imported poults as bacterial reservoir. Anim. Health Res. J., 4(4): 224-234.

29. Eid, S. and Samir, A.H. (2019) Extended-spectrum beta-lactamase and Class 1 integrons in multidrug-resistant Escherichia coli isolated from Turkeys. Vet. World, 12(7): 1167-1174.

30. Roth, N., Käsbohrer, A., Mayrhofer, S., Zitz, U., Hofacre, C. and Domig, K.J. (2019) The application of antibiotics in broiler production and the resulting antibiotic resistance in Escherichia coli: A global overview. Poult. Sci., 98(4): 1791-1804.

31. Awad, A., Arafat, N. and Elhadidy, M. (2016) Genetic elements associated with antimicrobial resistance among avian pathogenic Escherichia coli. Ann. Clin. Microbiol. Antimicrob., 15(1): 59.

32. National Veterinary Institute. (2011) SVARM 2010: Swedish Veterinary Antimicrobial Resistance Monitoring. The National Veterinary Institute (SVA), Uppsala, Sweden. Available from: https://www.sva.se/media/xw1drkpl/ svarm2011.pdf Retrieved on 30-05-2020.

33. Cohen, A.L., Calfee, D., Fridkin, S.K., Huang, S.S., Jernigan, J.A., Lautenbach, E., Oriola, S., Ramsey, K.M., Salgado, C.D. and Weinstein, R.A. (2008) Recommendations for metrics for multidrug-resistant organisms in healthcare setting settings: SHEA/HICPAC position paper. Infect. Control Hosp. Epidemiol., 29(10): 901-913.

34. Osman, K.M., Kappell, A.D., Elhadidy, M., ElMougy, F., El-Ghany, W.A.A., Orabi, A., Mubarak, A.S., Dawoud, T.M., Hemeg, H.A., Moussa, I.M.I., Hessain, A.M. and Yousef, H.M.Y. (2018) Poultry hatcheries as potential reservoirs for antimicrobial-resistant Escherichia coli: A risk to public health and food safety. Sci. Rep., 8(1): 5859.

35. Paterson, D.L. and Bonomo, R.A. (2005) Extendedspectrum beta-lactamases: A clinical update. Clin. Microbiol. Rev., 18(4): 657-686.

36. Costa, D., Vinué, L., Poeta, P., Coelho, A.C., Matos, M., Sáenz, Y., Somalo, S., Zarazaga, M., Rodrigues, J. and Torres, C. (2009) Prevalence of extended-spectrum beta-lactamase-producing Escherichia coli isolates in faecal samples of broilers. Vet. Microbiol., 138(3-4): 339-344.

37. Moawad, A.A., Hotzel, H., Awad, O., Tomaso, H., Neubauer, H., Hafez, H.M. and El-Adawy, H. (2017) Occurrence of Salmonella enterica and Escherichia coli in raw chicken and beef meat in Northern Egypt and dissemination of their antibiotic resistance markers. Gut Pathog., 18(9): 57.

38. Abraham, S., Jordan, D., Wong, H.S., Johnson, J.R., Toleman, M.A., Wakeham, D.L., Gordon D.M., Turnidge, J.D., Mollinger, J.L., Gibson, J.S. and Trott, D.J. (2015) First detection of extended-spectrum cephalosporin and fluoroquinolone-resistant Escherichia coli in Australian food-producing animals. J. Glob. Antimicrob. Resist., 3(4): 273-277.

39. Carattoli, A. (2008) Animal reservoirs for extended-spectrum beta-lactamase producers. Clin. Microbiol. Infect., 14(Suppl 1): 117-123.

40. Liebana, E., Gibbs, M., Clouting, C., Barker, L., CliftonHadley, F.A., Pleydell, E., Abdalhamid, B., Hanson, N.D., Martin, L., Poppe, C. and Davies, R.H. (2004) Characterization of beta-lactamases responsible for resistance to extended-spectrum cephalosporins in Esherichia coli and Salmonella enterica strains from food producing animals in the United Kingdom. Microb. Drug Resist., 10(1): 1-9.

41. Hoepers, P.G., Silva, P.L., Rossi, D.A., Júnior, E.C.V., Ferreira, B.C., Zuffo, J.P., Koerich, P.K. and Fonseca, B.B. (2018) The association between extended-spectrum beta-lactamase (ESBL) and ampicillin $\mathrm{C}(\mathrm{AmpC})$ beta-lactamase genes with multidrug resistance in Escherichia coli isolates recovered from turkeys in Brazil. Br. Poult. Sci., 59(4): 396-401.

42. Hasman, H., Mevius, D., Veldman, K., Olesen, I. and Aarestrup, F.M. (2005) B-Lactamases among extended-spectrum b-lactamase (ESBL)-resistant Salmonella 
from poultry, poultry products and human patients in The Netherlands. J. Antimicrob. Chemother., 56(1): 115-121.

43. Solà-Ginés, M., Cameron-Veas, K., Badiola, I., Dolz, R., Majó, N., Dahbi, G., Viso, S., Mora, A., Blanco, J., Piedra-Carrasco, N., González-López, J.J. and MiguraGarcia, L. (2015) Diversity of multi drug resistant avian pathogenic Escherichia coli (APEC) causing outbreaks of colibacillosis in broilers during 2012 in Spain. PLoS One, 10(11): e0143191.

44. Dierikx, C., van Essen-Zandbergen, A., Veldman, K., Smith, H. and Mevius, D. (2010) Increased detection of extended-spectrum beta-lactamase-producing Salmonella enterica and Escherichia coli isolates from poultry. Vet. Microbiol., 145(3-4): 273-278.

$* * * * * * * *$ 